\title{
THE GROWTH OF 'GRASSLANDS TAMA' WESTERWOLDS RYEGRASS ALONE: AND IN MIXTURE WITH CEREALS
}

\author{
E. W. VARTHA and S. J. RAE" \\ Grasslands Division, DSIR, Lincoln Regional Station, Private \\ Bag, Christchurch
}

\section{Abstract}

\begin{abstract}
In autumn-sown greenfeed trials on a Templeton silt loam following cereal cropping, the herbage yield from 'Grasslands Tama' Westerwolds ryegrass at first grazing in July and the subsequent regrowth to late August was 27\% higher than from 'Grasslands Paroa' Italian ryegrass. The margin in yield was less where both grasses were spelled until late August.

Subsequent regrowth in spring was similar for both grasses where there was one prior grazing in late winter, but growth of. Paroa was less than Tama ryegrass where there were two prior grazings in mid- and late winter. Grazing twice in July and August gave a $27 \%$ higher total yield from Tama ryegrass than a single grazing in late August. Yields of both grasses were higher with $67 \mathrm{~kg} / \mathrm{ha}$ than with $22 \mathrm{~kg} / \mathrm{ha}$ of nitrogen at drilling. Both grasses responded to further nitrogen applied in mid-winter, Paroa more so than Tama ryegrass.

Up to late winter, Amuri oats outyielded Tama ryegrass and C.R.D. ryecorn. Yields from an oats-Tama ryegrass mixture were $25 \%$ higher than from Tama ryegrass alone. They gave higher yields than Tama ryegrass alone to mid-winter when the cereal dominated, and provided as good recovery growth as Tama ryegrass alone in late winter and spring. when ryegrass dominated.
\end{abstract}

\section{INTRODUCTION}

SUPPLEMENTARY GREENFEED for winter and early spring grazing in Canterbury may be obtained from annual or biennial grasses and cereals sown in autumn. The tetraploid 'Grasslands Tama' Westerwolds ryegrass (Lolium multiflorum Lam.) is a recent addition to the range of materials that may be used. Its general growth characteristics have been described by Barclay and Vartha (1966) and Barclay (1969). On a high fertility Wakanui silt loam at Lincoln, Tama ryegrass consistently out-yielded 'Grasslands Paroa' Italian ryegrass ( $L$. multiflorum Lam,.) when sown

*Present address: Geigy Limited, Christchurch. 
in autumn with yields measured to late spring. 'C.R.D.' ryecorn (Secale cereale L.) out-yielded Tama ryegrass in early winter, but later, Tama ryegrass out-yielded ryecorn. Similar results from Tama ryegrass and cereal comparisons have been shown in South. land (Johnston and Harris, 1969) and Wairarapa (Crouchley and Bircham, 1971). The latter authors reported higher yields from oats than Tama ryegrass when sown in April and grazed in August, late August and September, but considerably lower yields from oats than Tama ryegrass when sown in March and grazed in May, June, August and September. They also showed a reduction in yield of Tama ryegrass with a delay in sowing from late February to early May.

In arable rotations, greenfeed may be grown after white straw crops and thus be sown later in autumn and under lower fertility than where grown as the first crop after cultivation of old pasture. Because establishment of Tama ryegrass is slow compared with cereals, it may be desirable to sow these greenfeeds in mixtures to obtain early production from the cereal and later production from the grass. In farm practice, a combination of cereal and grass is obtained where volunteer cereals "strike" following drilling of Tama ryegrass into stubble.

Greenfeed may in part be break-grazed by pregnant ewes for a period of one month prior to lambing and then set-stocked, thus placing less reliance on regrowth of the earlier-grazed area for later feeding. The alternative management of greenfeed with good regrowth would be rotational grazing,

\section{EXPERIMENTAL}

Experiment 1 compared growth of Tama and Paroa ryegrasses on a Templeton so41 at Lincoln. The area was previously in potatoes followed by wheat.

The trial was of the following design with three replicates.

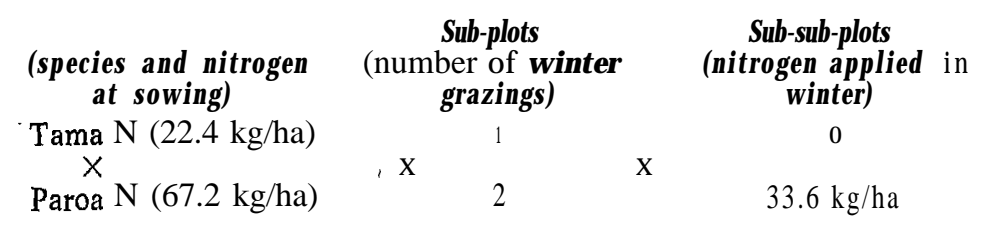

Seed was drilled in $15 \mathrm{~cm}$ rows on March 14, 1967, at rates of 33.6 and $22.4 \mathrm{~kg} / \mathrm{ha}$. of Tama and Paroa ryegrass, respectively. At the same time, calcium ammonium nitrate, was drilled at the lower rate of $\mathrm{N}$ or, at the higher rate, one-third was drilled and 
the rest broadcast. A basal dressing of $188 \mathrm{~kg} / \mathrm{ha}$ superphosphate was drilled with the nitrogen fertilizer. Additional winter nitrogen was applied to the appropriate plots in the first week of July immediately after the first grazing.

Grazings occurred on July 4 and August 31 , or on August 31 only, to simulate rotational grazing or break/set stocking systems, respectively. Sufficient sheep were used to graze to a stubble length of $2.5 \mathrm{~cm}$ in 48 hours.

Yield measurements from four $0.25 \mathrm{~m}^{2}$ quadrats per treatment were made just prior to each grazing and again on October 14 for the winter nitrogen treatment only to ascertain the effects of the grazing system on spring production.

Experiment 2 compared the growth of Tama ryegrass, C.R.D. ryecorn and Amuri oats, alone and in cereal-ryegrass mixtures, on a similar site to the first experiment, and previously in wheat. The trial was again a split-split plot design of three replicates with species and mixtures as the main plots and the subplots of grazing and nitrogen treatments similar to those in Experiment 1.

Tama ryegrass was drilled at $33.6 \mathrm{~kg} / \mathrm{ha}$ alone or $22.4 \mathrm{~kg} / \mathrm{ha}$ with cereals, while C.R.D. ryecorn and Amuri oats were drilled at 134 and $112 \mathrm{~kg} / \mathrm{ha}$, respectively, whether alone or with ryegrass. Basal dressings of calcium ammonium nitrate $(22.4 \mathrm{~kg} / \mathrm{ha}$ $\mathrm{N})$ and superphosphate (188 $\mathrm{kg} / \mathrm{ha})$ were drilled at sowing, on March 26, 1968. Three plots of Tama ryegrass were sown in addition to the main experiment. In these plots seed was drilled with superphosphate only, to give a comparison of production in the absence of nitrogen at drilling. Nitrogen at $33.6 \mathrm{~kg} / \mathrm{ha}$ was applied to sub-plots in late July.

Plots were grazed and herbage yields measured on July 22 and August 31 or on August 31 only, and further herbage yields following the August grazings were measured on September 18. Ryecorn was not cut in September because it was running to seed, while oats recovered poorly from grazing and production was not measured after the initial July or August grazings. Grazing methods and herbage measurements were similar to those in Experiment 1.

\section{RESULTS}

\section{EXPERIMENT 1}

Where $67.2 \mathrm{~kg} / \mathrm{ha}$ of nitrogen were applied at sowing, yields of both grasses at July 4 and of Tama ryegrass at August 31 were significantly higher (Table 1) . 
TABLE 1: EFFECT OF NITROGEN AT DRILLING (14/3/67) ON DRY MATTER YIELDS OF TAMA AND PAROA RYEGRASSES (kg/ha)

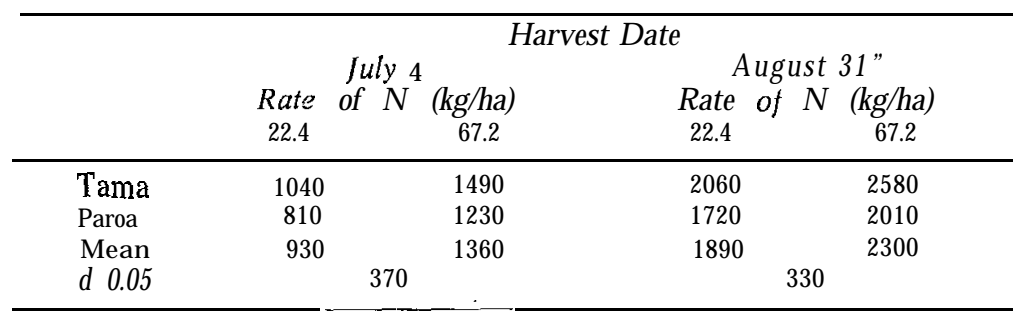

"Mean of grazing treatments at August 31.

Application of nitrogen at mid-winter had a significantly greater effect in increasing the yield of Paroa as compared with Tama ryegrass (Table 2 ).

TABLE 2: EFFECT OF NITROGEN AT MID-WINTER ON DRY MATTER YIELDS OF TAMA AND PAROA RYEGRASSES $(\mathrm{kg} / \mathrm{ha})$ Harvest Date - August 31*

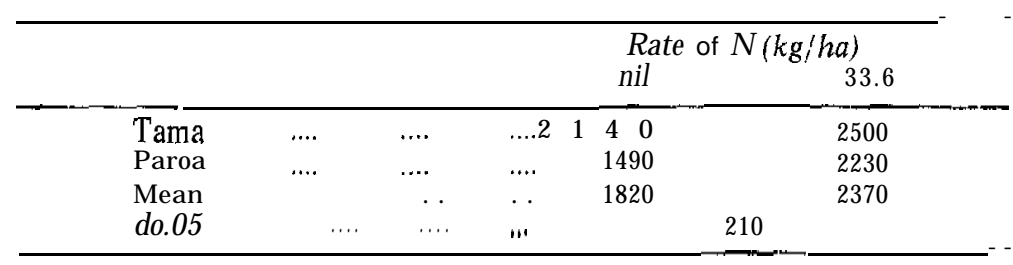

*Mean of grazing treatments at August 31.

The total growth of Tama ryegrass to late winter when previously grazed once was significantly higher than when not grazed (Table 3).

TABLE 3: EFFECTS OF GRAZING TREATMENTS ON DRY MATTER YIELDS OF TAMA AND PAROA RYEGRASSES (kg/ha)

\begin{tabular}{|c|c|c|c|c|c|c|}
\hline & Jul. & $\begin{array}{c}\text { Two Grazings } \\
\text { Aug. }\end{array}$ & Total & $\begin{array}{c}\text { One } \\
\text { Grazing } \\
\text { in } \\
\text { Aug. }\end{array}$ & $\begin{array}{l}\text { Recovery } \\
\text { One Prior } \\
\text { Grazing }\end{array}$ & $\begin{array}{l}\text { Spring* } \\
\text { Two Prior } \\
\text { Grazings }\end{array}$ \\
\hline Tama & 1270 & 2120 & 3390 & 2520 & 1970 & 2240 \\
\hline Paroa & 1020 & 1480 & 2500 & 2250 & 2140 & 1620 \\
\hline Mean & 1150 & 1800 & 2950 & 2390 & 2060 & 1930 \\
\hline d 0.05 & 370 & 270 & 330 & 330 & \multicolumn{2}{|c|}{540} \\
\hline
\end{tabular}

* Mid-winter $\mathrm{N}$ treatments only, 
In treatments where nitrogen had been applied in mid-winter, the growth of Tama ryegrass in spring was not affected by previous grazing management, but the growth of Paroa ryegrass was significantly lower where it had been grazed in mid-winter. The total yield of dry matter from March to September with higher $\mathrm{N}$ at drilling, mid-winter $\mathrm{N}$ and two winter grazings was 6480 and $4760 \mathrm{~kg} / \mathrm{ha}$ for Tama and Paroa ryegrasses, respectively.

\section{EXPERIMENT 2}

Tama ryegrass gave a similar yield at July 22, whether or not nitrogen was applied at drilling. There was no significant effect from the mid-winter application of nitrogen. At July 22 Amuri oats significantly outyielded Tama ryegrass and C.R.D. ryecorn, while yields for grass-cereal mixtures were similar to cereals sown alone (Table 4).

TABLE 4: EFFECT OF GRAZING TREATMENTS ON DRY MATTER YIELD OF FIVE GREENFEED SPECIES OR MIXTURES (kg/ha)

\begin{tabular}{|c|c|c|c|c|c|c|}
\hline & \multirow[b]{2}{*}{${ }_{u l}^{\mathrm{Tw}}$} & \multirow{2}{*}{\multicolumn{2}{|c|}{0 G razings }} & \multirow{2}{*}{$\begin{array}{c}\text { One } \\
\text { Crazing }\end{array}$} & \multicolumn{2}{|c|}{ Recovery in Spring" } \\
\hline & & & & & $\begin{array}{c}\text { One Prior } \\
\text { Grazing }\end{array}$ & $\begin{array}{c}\text { Two Prior } \\
\text { Grazings }\end{array}$ \\
\hline Tama ryegrass & 1690 & 1170 & 2860 & 2490 & 1150 & 1410 \\
\hline C.R.D. ryecoln & 1600 & 960 & 2560 & 2250 & -+ & - \\
\hline Amuri oats & 2670 & $-\mathrm{t}$ & 2670 & 3340 & - & - \\
\hline Ryegrass-ryecorn & 1670 & $1340^{\circ}$ & 3010 & 3240 & 1020 & 1580 \\
\hline (\% cereal ) & (71) & $(56)$ & (64) & (84) & (8) & $(3)$ \\
\hline Ryegrass-oats & 2520 & 1180 & 3700 & 3340 & 1010 & 2010 \\
\hline$(\%$ cereal $)$ & (89) & (38) & (64) & (77) & (27) & (17) \\
\hline d 0.05 & 510 & 315 & 420 & 420 & & 540 \\
\hline
\end{tabular}

*Mid-winter $\mathrm{N}$ treatments only.

†No recovery after first grazing.

†Run to seed - not harvested.

The cereal was the dominant component of the mixture at this stage. Oats sown alone did not recover from the mid-winter grazing. By late winter, when not previously grazed, oats and cerealgrass mixtures outyielded Tama ryegrass and C.R.D. ryecorn, but, when previously grazed, greenfeeds generally gave similar yields at the second harvest. Total growth to late winter was, except for oats, not significantly different for both grazing treatments.

In spring, yields of grass-cereal mixtures were similar to grass alone. At this stage, Tama composed more than $73 \%$ of the mixture. Production from the ryegrass-oats mixture was significantly 
higher where. the treatments were previously grazed in mid- and late winter as compared with late winter only. Where two winter grazings were carried out, the highest dry matter yield for the period March to September was obtained from the ryegrass-oats mixture with $5710 \mathrm{~kg} / \mathrm{ha}$, while Tama alone yielded $4270 \mathrm{~kg} / \mathrm{ha}$.

\section{DISCUSSION}

Previous experiments on a high fertility Wakanui silt loam. at Lincoln showed that, with a February sowing and grazed two or three times in winter, Tama outyielded Paroa ryegrass by 27 to $41 \%$ (Barclay and Vartha, 1966). No comparison was made of herbage spelled throughout winter because, with high growth rates under high fertility, there would be considerable reduction in yield potential if left ungrazed for a long period. In the present Experiment 1, sown later after a cereal crop and consequently with a lower potential yield than in previous experiments, Tama outyielded Paroa ryegrass by $27 \%$ where grazed twice in winter, but yields were similar where grazed only once. The higher yield of Tama was due to its superior regrowth after mid-winter grazing together with reduced growth of Paroa ryegrass in spring, after two grazings in winter.

In farming practice, the general tendency is not to rotationally graze greenfeed, but rather to ration graze with hay supplement and then later set-stock graze. The latter management does not take full advantage of the good winter regrowth characteristics of Tama ryegrass. A reduction in hay feeding could be achieved by growing more grass through rotational grazing than can be grown when the bulk of the crop is spelled at or near ceiling yield to late winter. In the mild winter conditions experienced during Experiment 1 , regrowth of Tama ryegrass after a mid-winter grazing gave $80 \%$ of the yield of the treatment spelled to late winter. In the wet winter conditions experienced during Experiment 2, regrowth of Tama ryegrass after a mid-winter grazing gave $47 \%$ of the yield of the treatment spelled to late winter. However, the date of mid-winter grazing relative to late winter grazing was about three weeks later than in Experiment 1, because wet ground conditions precluded earlier grazing. A further factor to consider is the quality of herbage and this would probably be higher for less mature herbage from mid-winter regrowth after grazing, than for herbage spelled for a considerable time.

An observed weakness in the growth characteristics of Tama ryegrass as compared with cereals has been its slow growth in early winter. As shown in Experiment 2, oats outyielded Tama 
ryegrass to mid-winter by $36 \%$, but to late winter the margin was reduced to $25 \%$. In contrast to results from previous experiments (Barclay and Vartha, 1966) similar yields to midand late winter were obtained from Tama ryegrass and ryecorn. Probably because sowing date was later, ryecorn was unable to express its advantages of better ability than Tama ryegrass to establish under dry conditions in early autumn.'

There was negligible regrowth of oats after mid-winter grazing in contrast with Tama ryegrass and ryecorn. One of the features of Tama ryegrass is good growth in early spring. The quality of feed from ryecorn deteriorates rapidly in spring because of its. early flowering.

Mixtures of cereals with Tama ryegrass were studied \&determine whether these might have advantages in either higher yields than ryegrass or cereals alone, or a better seasonal balance of production. Total yields to late-winter, whether grazed or not in mid-winter, were about $25 \%$ higher from oats-Tama ryegrass mixtures than from Tama ryegrass alone. The mixtures had the advantage of higher yields than Tama ryegrass to mid-winter and as good recovery growth in late winter and spring. Mid-winter grazing of the mixtures considerably reduced the cereal contribution and increased grass contribution in late winter and spring, compared with those spelled right through to late winter.

The yield advantage of the cereal-grass mixture in early winter requires economic assessment in animal production experiments to determine whether the cost of cereal seed additional to Tama seed is warranted,

The results from Experiment 1 showed that the higher rate of nitrogen at drilling produced an extra $10 \mathrm{~kg}$ of dry herbage by mid-winter for each additional kilogram of nitrogen. A similar response was obtained from nitrogen applied to Tama ryegrass in mid-winter, but almost double this return was measured from Paroa ryegrass. No significant interacting effects of drilling nitrogen or grazing treatment were shown. The authors have observed, in other work in the Lincoln district, that urine patches in winter were more marked on Paroa ryegrass than on Tama ryegrass growing in separate sowings in the same paddock.

In Experiment 2, no response was obtained with the nitrogen application to Tama ryegrass at drilling. This was probably- because a cyclonic storm in April resulted in $165 \mathrm{~mm}$ of rainfall, which kept the ground extremely wet throughout most of the winter. There was no significant growth response to mid-winter nitrogen up to late winter in that year, but the regrowth period 
was about three weeks shorter than for the previous year. The rate of growth in spring of Tama ryegrass given a mid-winter application of nitrogen was 65 to $80 \mathrm{~kg} / \mathrm{ha} /$ day for 18 days in Experiment 2 compared with 45 to $50 \mathrm{~kg} / \mathrm{ha} /$ day for 44 days in Experiment 1 . General experience at Lincoln with Tama ryegrass has been a consistent response of increased early spring growth to mid-winter applications of nitrogen even on fertile Wakanui silt-loam (Vartha, unpublished).

The value of Tama ryegrass in Canterbury is as a high quality 'feed in late winter and early spring. Unless early vigour can be obtained in this species by further plant breeding, cereals and autumn-grown permanent pasture species will remain the source of early winter feed, as required particularly for milking and fattening stock. A combination of cereal with grass seems a feasible alternative. Increased emphasis should be placed on the ability of Tama ryegrass to regrow in the cool season, thus providing an opportunity for greater cumulative total yield, of probably higher feeding quality, than when it is spelled for a considerable time at ceiling yield. Nitrogen application seems worth while after fertility depleting crops, to ensure both quantity and quality of feed.

\section{ACKNOWLEDGEMENT}

Miss E. M. Stevenson, Applied Mathematics Laboratory, DSIR, Lincoln, for statistical analyses.

\section{REFERENCES}

Barclay, P. C., 1969: N.Z. Journal of Agriculture, 118: 22.

Barclay, P. C.; Vartha, E. W., 1966: Proceedings of the N.Z. Grassland Association, 28: 184.

Crouchley, G.; Bircham, J. S., 1971: ibid., 722: 36.

Johnston, J. M.; Harris, A. J., 1969: ibid., 119: 45. 